\title{
Financial Inequity in Basic Education in Selected OECD Countries
}

\author{
Yu Zhang (Corresponding author) \\ Teachers College, Columbia University
}

Box 211C, 525W 120th St., New York, NY, 10027, USA

Tel: 1-212-678-3814 E-mail: yz2219@columbia.edu

Suguru Mizunoya

Teachers College, Columbia University

Box 211C, 525W 120th St., New York, NY, 10027, USA

Tel: 1-212-678-3814Ｅ-mail: suguru777@gmail.com

You You

Teachers College, Columbia University

Box 211C, 525W 120th St., New York, NY, 10027, USA

Tel: 1-212-678-3814 E-mail: yy2242@columbia.edu

\author{
Mun Tsang \\ Teachers College, Columbia University
}

Box 211C, 525W 120th St., New York, NY, 10027, USA

Tel: 1-212-678-3814 E-mail: mct27@columbia.edu

(C) Do not quote without prior permission from authors.

Received: February 22, 2011 Accepted: February 28, 2011 doi:10.5539/ies.v4n3p3

\begin{abstract}
This is a study of financial disparities in primary and secondary education in OECD countries that have a relatively large population and a school finance system with decentralized features. These countries include the United States, Britain, Australia, Spain, Canada, and Japan. There are two major research questions: What are the trends in disparities in per-student education spending during the 1990s and early 2000s period? What government policies or factors may explain these trends? Common statistics such as the coefficient of variation, the restricted range, the federal range ratio, and Gini coefficient are used to measure disparity in per-student spending. Sub-national data for this study are obtained from published government sources. There are three major findings: (1) there was a general trend towards a reduction in inequity in per-student education spending in these countries; (2) this equalization trend was associated with a variety of financing policies implemented in these countries; and (3) a larger share of regional government funding relative to the share of local government funding, intergovernmental transfer, and the design of school funding formulas are crucial factors for enhancing equity in education funding. The policy towards centralization in education finance system also appears to be an important factor in financial equalization.
\end{abstract}

Keywords: Equity in basic-education finance, OCED countries, Intergovernmental transfer, Decentralization

\section{Introduction and Methodology}

\subsection{Disparity and Inequity in Basic-education Finance: Conceptual Issues}

It is generally recognized that basic education (primary and secondary education) is an important public good and that equal opportunity should be provided to children from various socioeconomic backgrounds. Promoting equality in school funding is an important part of the effort to guarantee equal education opportunities; and thus reducing financial disparities in basic education is a key issue in education in many countries. 
Equity in education finance refers to fairness in the mobilization and distribution of resources in education (Levin, 1995; Tsang \& Ding, 2007). In examining education finance equity, one important question to raise is "fairness to whom?" The targeted group could be students, taxpayers, and teachers, depending on the object of education policy. Equity in education can be evaluated with respect to four aspects of the education system: inputs, process, outputs, and outcomes. And there are several standards or approaches for equity assessment in basic-education finance (Yinger, 2004): equality (e.g., equal funding for students from all backgrounds); fiscal neutrality (e.g, school funding not related to fiscal capacity of school districts); and adequacy (e.g, assuring an adequate level of funding to achieve a sound education for students from all background).

There is a large literature on studies to assess financial disparities in basic education in different countries. However, few of them did cross-national studies. Countries with different school funding structure, taxation, and education expenditure distribution mechanisms may present different levels of disparity and different trends of disparity. This study presents a cross-national analysis of financial disparities in basic education in populous OECD countries (with a population of at least 20 million people) with an education finance system involving more than one level of government and the use of intergovernmental education grants. These countries include the United States, Britain, Australia, Spain, Canada, and Japan. The study addresses two research questions: What are the trends in disparities in public per-student spending in basic education during the 1990s and early 2000s? What government policies or factors may explain these trends? In short, this research on financial disparity is a study of equity in basic-education finance that is targeted at students, focusing on financial input to education, and based on the equality-standard of equity.

In this study, several factors in the process of resource mobilization and resource allocation are examined to ascertain their impact on financial disparity (Tsang \& Ding, 2007; Baker et. al., 2007). These factors include the shares of government spending on education by level of government and their change over time, the trend in decentralization/centralization in resource mobilization over time, the role of intergovernmental transfer, the mechanism that determines public funding for each student (such as school funding formulas), and special central government programs aiming at reducing financial disparity.

Studies of education finance and governance tend to associate decentralized education systems with broader participation, better resource mobilization, and higher efficiency (Weiler, 1990; Hansen, 1995). Decentralization might mobilize resources that are not available under more centralized conditions; decentralized systems might also utilize available resources more efficiently, because of more information observed and more freedom to adjust decisions according to local needs. On the other hand, centralization may be associated with standardization and uniformity in education and greater effectiveness due to economies of scale. Thus, depending on the educational goals, there are trade-offs between decentralization and centralization in education finance. In this study, financial decentralization/centralization is measured as the increasing/decreasing share of local government funding.

Intergovernmental grants are grants from higher levels of government to lower levels of government. The government may use intergovernmental grants to achieve both horizontal and vertical equity. Tsang (2001) and Guthrie \& Rothstein (1999) define intergovernmental grant schemes as an important part of the school finance system in a decentralized context because it ensures minimum adequate level of education and reduces excessive financial disparities among such units. The two major aims of the system are targeting resources at the most disadvantaged populations; and reducing disparities in education funding. There are several common types of intergovernmental grants: block grants, categorical grants, and revenue sharing grants. Block grants refer to the types of grants that are given as a general aid to education. It could be in the form of flat grants (in proportion to the average daily attendance per district), or in a foundation grant (providing a minimum level of educational expenditures that has to be guaranteed to each of the districts, regardless of the level of revenue raised.) This kind of grant allows local units to allocate and use the money in their own ways because it does not place restrictions in the uses of money. Categorical grants are for particular types of educational services that are considered to be in the national interest. The best known among these are grants for bilingual education, special education, vocational education, and aid for federally impacted areas. Categorical grants need to be used for some specific purposes. General revenue sharing grants are intended to provide an equal basic per-pupil property tax base to each district, which may lead to more involvement of a higher-level government in poor local districts. This study focuses on intergovernmental grants within the education sector. It is possible that intergovernmental grants in other sectors may have an education component; but such grants for education are generally small and information is not easily available.

School funding formula is a common policy tool to allocate education funding, especially in English speaking countries, such as the U.S., UK, Australia, and Canada. It is easily written into law and easy to audit. Governments use school funding formula to achieve both horizontal equity (equal treatment of equals) and vertical equity 
(unequal treatment of unequals) by using weighted-pupil formulas. Even in a decentralized funding system, if local governments are subject to school funding formula act, equity and adequacy could be enhanced (Cohn \& Geske, 1990).

\subsection{Methodology}

Common statistics such as coefficient of variation, the restricted range, the federal range ratio, and Gini coefficient are used to measure disparities in per-student spending. In defining education equity as equal opportunity in education, disparities in per-student spending are measures of equity in educational spending. All the indicators are calculated by authors using data published by each country at regional level (e.g. state or province level), unless stated otherwise. The definitions and evaluations of the four indicators are list below.

(1) Restricted Range: The difference between the districts in the $95^{\text {th }}$ and $5^{\text {th }}$ percentiles $\left(R_{95}-R_{05}\right)$ of the per student expenditure distribution. It eliminates potential outliers on both sides of the distribution that could influence the calculation of the range.

(2) Federal Range Ratio: The ratio of the $95^{\text {th }}$ to the $5^{\text {th }}$ percentile values of per student expenditure $\left(R_{95} / R_{05}\right)$. In this way, instead of evaluating absolute differences between these two values (restricted range), it calculates the "relative difference" between them (how many times higher is the $95^{\text {th }}$ percentile with respect to the $5^{\text {th }}$ percentile).

For both the restricted range and the federal range ratio, the bigger the value is, the bigger the disparity is. Zero means perfect equality. The strengths of these indicators are (i) Easy to calculate; (ii) Understandable; (iii) Elimination of potential outliers. The weaknesses are: (i) No distribution information; (ii) Ignores all information but only 2 observations.

(3) Coefficient of Variation (CV): It is the ratio of standard deviation (the squared root of the variance) to the mean.

$$
C V=\frac{S \cdot D}{\bar{X}} \cdot \text { or } \mathrm{CV}=\sqrt{\operatorname{var}(R)} / \bar{R}
$$

The coefficient of variation can take on any positive value, with zero indicating perfect equity and higher values indicating increasing inequity. It is easy to measure, but potentially the coefficient of variance is sensitive to extreme values due to a lack of weighting adjustment (outliers).

(4) Gini coefficient: It can be deduced from Lorenz Curve, which is a curve that illustrates the spending distribution.

$$
\begin{aligned}
& \text { Gini }=\frac{1}{\mu N(N-1)} \sum_{i>j} \sum_{j}\left|y_{i}-y_{j}\right| \\
& \mu=\text { mean of per }- \text { student spending } \\
& N=\text { number of observatio } n \\
& y=\text { dollar value of per }- \text { student spending }
\end{aligned}
$$

It has a range between zero (perfect equality) and one (perfect inequality). It takes into account only the area between the Lorenz curve and the perfect equity reference line, disregarding the shape of the curve. It is sensitive to the differences around the mode of the distribution. It is a generally accepted index in economics work, incorporates all data, and allows for comparison of units with different size population. The main weakness of this indicator is that it ignores the shape of the Lorenz curve.

It has to be clarified that the benchmark for finance equity is difficult to define, especially in cross national comparison, because the sizes of countries vary significantly, and the economic and demographic conditions are very complex to be fully controlled when comparing education finance equity. In addition, one cannot say that financial systems with smaller disparity indicators perform better than financial systems with larger disparity indicators, because some systems pay more attention to vertical equity, efficiency, and financial neutrality, which might conceal the horizontal equity level due to the diverse characteristics of student bodies in different regions across countries.

\subsection{Basic Information of the Six OECD Countries}

This study focuses on advanced industrialized countries with varying degree of decentralization in education finance and the use of intergovernmental grants in education. They are relatively large countries in terms of population (at least 20 million people) and may not be characterized by some unusual conditions of the small states or city states. 
The selection of the six OECD countries allows for ease of access to available information with similar definition of terms. Besides the interest on the OECD countries themselves, the education-finance experience and practices of OECD countries may sometimes be examined by other countries.

Table 1 reports basic socioeconomic indicators of each country. The Human Development Index in Canada is the highest in 2006, and in the United Kindom is the lowest. The United States has the highest per capita GDP and population. The Gini index in Japan is the lowest, and in the U.S. is the highest. The United Kingdom has the highest government spending as $\%$ of GDP.

Table 2 reports indicators of educational development. The net enrollment rates (NER) of Japan for both primary and secondary education are all $100 \%$, while the NERs in Australia are $97 \%$ and $86 \%$ respectively, and in the U.S. are $92 \%$ and $89 \%$. In 2005 , the government expenditure on primary education as $\%$ of GDP in the U.S. is the highest, $3.7 \%$, and in Japan is the lowest, $2.7 \%$. The government expenditure on secondary education as $\%$ of GDP in the U.S. is the highest, $5.1 \%$, and again in the Japan is the lowest, $3.5 \%$.

Part 2 presents a concise summary of the findings on each of the six countries on the trend in disparity indicators for per-student public education spending, on the trend in funding share by government level, and on government policies for equalization. Part 3 synthesizes the findings from the six cases and compares trends of disparities, shares of school funding by government level, trends of centralization/decentralization, distributional mechanism (e.g. school funding formula), and special government programs to enhance equity. Part 4 is conclusion and discussion of further research.

\section{Case Studies of Financial Inequity in Basic Education (Note 1)}

\subsection{The United States}

Table 3 represents the trend in disparities of the per-student public recurrent expenditure of all the 50 states and D.C. for pre-kindergarten to secondary education in the USA from 1993 to 2005. The figures are in constant 2005 dollars.

The restricted range decreased from 5,506 dollars in 1993 to a low of 3,993 dollars in 2001 but increased rather rapidly to $\$ 5,260$ in 2005 . The Federal range ratio of 1993 was 2.18 , which means that the difference between the highest $95 \%$ value and the value of lowest $5 \%$ was $118 \%$ of the value of the lowest $5 \%$. Federal range ratios decreased from 2.18 in 1993 to 1.69 in 2000 then slowly increased to 1.80 in 2005 . The coefficient of variation is around 0.22, and quite similar for the observed period. The value decreased from 0.244 in 1993 to 0.201 in 2000, then increased to 0.223 in 2005. The average of Gini coefficient from 1993 to 2005 was 0.117 . It was 0.131 in 1993, decreased to 0.108 in 2000 , and then slowly increased to 0.120 in 2005 . This pattern is basically similar to that of other inequality indicators.

According to Table 4, the average share of federal government funding for public primary and secondary education creased from $7.49 \%$ in 1997 to $9.69 \%$ in 2006 , the share of state government decreased from $50.00 \%$ in 1997 to $38.60 \%$ in 2006 , and the local government share increased from $42.51 \%$ in 1997 to $51.70 \%$ in 2006 . On the other hand, the average share of actual expenditure of the three levels of government is $0.48 \%, 0.92 \%$, and $98.60 \%$, respectively in 2006. It suggests that (a) the transfer from state government to local government accounts for $46.90 \%$ of the total expenditure in 2006 and state government plays an important financial equalization role within a state, and that (b) the role of the federal government to address financial inequalities is fairly limited (the intergovernmental transfer from central government only accounts for $9.20 \%$ in 2006 . In addition, the declining share of state government funding and increasing share of local government funding are consistent with the increase of disparity indicators from 1998 to 2005.

We can observe a big change between 2000 and 2001. According to the original OECD data, before 2000, federal government transfer went to local government directly; while from 2001, this transfer went to state government, and was transferred to local government together with state government transfer. In addition, the share of state government funding dropped about 10\% from 2000 to 2001, and the share of local government funding increased about $10 \%$ in the same period.

Although the federal government and state government reduce part of the financial disparity across districts, significant disparity still persists. From the late 1980s, a comparatively new legal paradigm of educational adequacy emerged. It emphasizes resource adequacy (that is, adequate resources to ensure a sound education), rather than equity in available resources based on equality or other standards. This new paradigm of educational adequacy has spread rapidly in recent years and now serves as the foundation for many current court cases and legislative deliberations (Ladd et al., 1999). If the minimum adequate level is above the lowest per student expenditure in some districts, the pursuit of adequacy may reduce disparity among districts and then improve equity.

The U.S. Congress passed the "No Child Left Behind Act" (NCLB) in 2001. NCLB reauthorized the Elementary and 
Secondary Education Act (ESEA) -- the main federal law affecting education from kindergarten through high school. NCLB is built on four principles: accountability for results, more choices for parents, greater local control and flexibility, and an emphasis on doing what works based on scientific research (Note 2). Although NCLB does not target at financial equity directly, it does focus on output equity through its emphasis on improved performance of low-performance schools and the reduction of the achievement gaps between students of different backgrounds.

In February 2009, President Obama signed the American Recovery and Reinvestment Act which included 100 billion dollars for spending on education. The education spending aims to stem huge cuts by states, fund programs for special education, low-income students, and early-childhood initiatives, and provide incentive to everyone, from teachers to state officials, to think in terms of reform (Note 3).

\subsection{The United Kingdom (UK)}

The Combined Local Education Authority and School Based Expenditure per Pupil data published by the UK National Statistics and Department of Children, Schools and Families are from 1996 to 2004. Due to limitation in data availability, only the disparity indicators within England were computed for primary and secondary (lower and upper) education.

According to Table 5, the Gini coefficient, federal range ratio, restricted range, and coefficient of variation have the similar trend. All the indicators decreased from 1997 to 2001, and increased a little bit from 2001 to 2004. The restricted range is also a V-shape curve during 1996-2004, but the low point was in 2000, not 2001.

In England, the use of formula-based block funding guarantees basic horizontal equity, at least in each local authority, because the proportion of funding to schools must be based on pupil numbers (Simkins, T., 2003). However, during the 2001-2007, there was no significant or particular government policy or program aimed at enhancing financial equity.

For primary to secondary education, the share of central government spending before intergovernmental transfer increases with fluctuation from $8.02 \%$ in 1997 to $16.98 \%$ in 2004 (Table 6), indicating a centralizing shift. This is consistent with the fact of decreasing disparity in primary education and the common assumption that centralized financial system will lead to higher level of equity.

\subsection{Australia}

The state level data published by The Ministerial Council on Education, Employment, Training and Youth Affairs (MCEETYA) and National Schools Statistics Collection (NSSC) are from 1999 to 2006. Table 7 reports the disparity indicators of per student public expenditure by education level. At the primary level, the Gini coefficient, federal range ratio, and coefficient of variation all show an obvious decrease from 1999 to 2006 . At the secondary level, both the coefficient of variation and the Gini coefficient also show a clear decrease during the same period, but the federal range ratio experienced a slight increase. But the pattern for the restricted range was different. At the primary level, the restricted range was a V-shape curve; it dropped rapidly from 1583 in 1999 to 500 in 2002 but rose rapidly to 1447 in 2006. At the secondary level, it rose from 1424 in 1999 to 3299 in 2004 but decreased to 2568 in 2006.

In terms of government spending on public institutions by levels of government, the regional government is the main agent to directly allocate funding to public institutions in Australia. Local government doesn't directly allocate any funding for education. Table 8 shows that, after the intergovernmental transfer, regional government spending on primary education accounted for more than $99 \%$ of all public spending at this level during the 1997-2006 period while the share for the central government was less than one percent. However, in terms of the source of spending before transfer, the share of the central government spending on primary education actually increased from $13.10 \%$ in 1997 to $17.60 \%$ in 2006, with a corresponding decrease in the share of the regional government during the same period. This indicates some shift towards centralization in funding in primary education from the regional to the central level. In secondary education, after the transfer, there was a slight decrease in the share of spending by the regional government from $89.33 \%$ in 1997 to $90.84 \%$ in 2006 and a corresponding increase in the central share. But in terms of spending by source before the transfer, the regional share increased from $80.05 \%$ to $84.00 \%$ during the $1997-2006$ period and the central share decreased from $19.95 \%$ to $16.00 \%$ during the same period. Thus there was a shift in decentralization from the central to regional level.

After reviewing the Australian Government Programs for Schools Quadrennial Administrative Guidelines from 1997 to 2008, we find no special policy or program to reduce financial disparities. However, the School Global Budget itself is a very good guarantee of financial equity. Schools with the same mix of learning needs are entitled to receive the same total funding in the School Global Budget. This means that it is important to obtain accurate and comprehensive information on those characteristics which best predict or define learning needs of students and to use this information in allocating financial resources to schools. 
The School Global Budget funding model identifies a series of principles which underpin the allocation of resources to schools. They are: the pre-eminence of educational considerations (the relative weighting of chosen factors should be based on educational considerations), fairness (schools with the same mix of learning needs should receive the same total resources), transparency (the basis for allocations should be clear and readily understandable), subsidiarity (decisions should be made centrally only if they cannot be made locally), accountability (a school which has received resources because of a certain student mix should be accountable for the use of resources, including students outcomes), and strategic implementation (new funding arrangements should be implemented progressively to eliminate dramatic change in a short period of time).

\subsection{Spain}

Table 9 gives the disparity indicators of per-student public education expenditure from 2000 to 2005. There are only two levels of education, because the original data combines pre-primary and primary education expenditures, and also lower secondary and upper secondary education.

At the primary level, the restricted range, the federal range ratio, coefficient of variation, and Gini coefficient also show a decrease from 2000 to 2005; and much of the decrease takes place in 2001. At the secondary level, the restricted range, the federal range ratio, coefficient of variation, and Gini coefficient all show a clear decrease from 2000 to 2005; and the decrease was gradual over the five-year period.

There are intergovernmental transfers in Spain, but they are not used specifically for education financing. They are equalization transfers to finance all the public services in a region. Their main purpose is to guarantee that every individual has access to the same public services independent of location of residence. This guarantee is applied for all the services provided by regions, not only for education. They use resources from general tax revenue (income tax, VAT, own taxes, etc). There are no specific taxes linked to education finance with the exception of taxes paid for university enrollment. However, those taxes only cover $10 \%$ of university expenditure. Regional governments assume the finance of almost all the expenditure in education (salaries, school facilities, etc) while municipal governments only have a residual role (security, nursery, etc.)

Thus, with regards to education expenditure, there is no special transfer from central to regional and local government or from regional to local government. According to Table 10, at the primary level, the share of central government funding was $40.04 \%$ in 1997 , but decreased to around $11.95 \%$ in 2006 . There was a huge drop from 1999 to 2000 . The share of regional government was $49.68 \%$ in 1997, and then increased to about $76.29 \%$ in 2006 . The share of local government in 1997 is $10.28 \%$. It decreased first to $9.78 \%$ in 1999 and began to increase again to $11.76 \%$ in 2006 . At the secondary level, the central share was reduced from $47.17 \%$ to $12.77 \%$ from 1997 to 2006 , the regional share increased from $48.48 \%$ to $84.13 \%$, and the local shared decreased from $4.35 \%$ to $3.10 \%$. At both the primary and secondary levels, the regional government is the major source of funding and its financing has become more dominant over time. The huge drop of the central government share in 2000 for both primary and lower secondary education was due to the completion of the decentralization reform of the regions. This event was reflected in education finance (Carbonell, J., Alcalde A., 2008).

\subsection{Canada}

Table 11 presents the trends of disparity indicators of the per-student total public expenditure for Pre-Elementary, Elementary and Secondary education from 1998 to 2005. For the federal range ratio, the coefficient of variation, and Gini coefficient, the value of the indicator in 1998 was quite close to that in 2005 . However, the indicator did experience some fluctuations between 1998 and 2005: it dropped sharply from 1998 to 1999, regained the loss between 1999 and 2004, and then experience a relatively small drop between 2004 and 2005. However, the pattern was different for the restricted range; this indicator experienced a significant increase from 7,150 in 1998 to 9,053 in 2005.

In Canada, there is no federal agency responsible for education; each of the thirteen regional jurisdictions (provinces) is responsible for education in pre-elementary, elementary, and secondary education. This might be the main reason for the high disparity at the provincial level. It is consistent with the information provided in Table 12: the share of federal government funding for public school is very small, around $4 \%$. The share of regional government spending on education increases from $60.67 \%$ in 1997 to $70.59 \%$ in 2006.

The Equalization and Territorial Formula Financing (TFF) programs provide unconditional transfers to the provinces and territories. Equalization enables less prosperous provincial governments to provide their residents with public services that are reasonably comparable to those in other provinces, at comparable levels of taxation. TFF provides territorial governments with funding to support public services, in recognition of the higher cost of providing programs and services in the north. 


\subsection{Japan}

Table 13 reports the trend disparity indicators of the per-student total public education expenditure of all the 47 provinces in Japan for different level of education from 1998 to 2004. For both primary education and lower-secondary education, the indicators of federal range ratio, coefficient of variation, and Gini coefficient show that there was little change in disparity between 1998 and 2004. For upper-secondary education, the indicators show that there was a reduction in disparity, but the reduction was quite modest. Overall, the extent of disparity in basic education in Japan is quite stable over time. For the restricted range during 1998 and 2004, there was a slight increase at the primary level, a slight decrease at the lower-secondary level, and a modest decrease at the upper-secondary level.

Table 14 presents the shares of Central, Regional, and Local government of financing different level of education, before the transfer and after the transfer (Note 4). After the transfer, the role of central government is very limited, and the majority of expenditures come from regional government. However, the before transfer figures, which presents the source of funding by the level of government, show a very different picture. About $30 \%$ of funding for primary education and $31.1 \%$ of funding for lower secondary education come from the central government, whereas the share of regional government was around $45 \%$. Regarding the transfer to Local governments, the figures before and after the transfer are the same. There is no transfer to this level of government neither from Central nor Regional levels. It suggests that Transfer from Central government play an important role in financing compulsory education in Japan. The basic picture does not change for Upper Secondary schools, but the Central government involvement becomes a little lower. The name of the transfer from the central government to the provincial government is called National Treasury Disbursement. National Treasury Disbursements (NTD) is earmarked. The purpose of the NTD includes compulsory education, social assistance, child protection, and infrastructure construction. The compulsory education component of the NTD is the largest component and accounts for about $17.5 \%$ of NTD. (Note 5)

Table 14 also reports the trend of share of direct expenditure for public schools by level of government for primary and lower secondary education. Generally speaking, the trends of three levels of governments are very stable, and the changes across years are less than $1 \%$.

In Japan, there are measures to reduce disparities from the aspects of both legislation and financial allocation. According to the Ministry of Education, Culture, Sports, Science and Technology (Note 6), the provincial government plays a crucial role in school funding. The central government takes care of students with special needs. Although there is no clear definition of school funding formula, there are several laws to guarantee the same effects on equity. Detailed clauses are listed below.

a) The law of school education Article 5 speculates that the cost of schools established by local governments (village, town, and city) is born by the establisher. However, the provincial and central governments provide subsidy in order to ensure the equal education opportunity based on the Japanese constitution.

b) The provincial government is responsible for the salary of teachers in public elementary and junior high schools established by local governments (village, town and city) according to the law for the salary of school officials.

c) The law for basic education cost born by national treasury (1952) speculates that one-third of the salary of teachers in elementary, and junior high schools established by villages, towns, and cities, and schools for the handicapped, blind and Deaf-mutes are provided by the central government, and the transfer is made to the provincial government. The type of salary that is not covered includes the salary for the cooks for school lunch, and special type of part-time teachers. For those personnel, the local governments (village, town, city) should bear the salary cost.

d) The cost of school official for a local government is calculated based on the number of children (e.g. the number of standard children per class is first calculated by the number of children, from which the number of teachers required and their cost will be calculated), the cost of teacher salary. Both the standard pupil-teacher ratio and the teacher standard salary are defined by national laws. In other words, the number of school official and their salary are decided by the central government so that the class size and teacher treatment/compensation will not vary from a province to another.

e) If a provincial government wishes to employ more teachers than the national standard, it could do so but the cost will be born by the provincial government.

\section{Analysis of Financial Inequity across Countries}

\subsection{Trends of Financial Inequity across Countries}

To evaluate the trends of the school funding disparity, we employ the tool of gap reduction rate (GRR) (Note 7). 
Intuitively, the GRR measures the rate of progress toward a particular policy objective, such as reduction in per student expenditure. Technically, it is the coefficient of the regression of disparity indicators on time. If GRR is negative, we are closing the gap between the real disparity and the ideal equity level. The lager the absolute value of the GRR, the faster the disparity indicator is decreasing. If GRR is positive, disparity becomes more severe. In this part, we only review the trends of Coefficient of Variations and Gini Coefficient. Table 15 and Table 16 report the basic statistics and GRR for the time series of the two disparity indicators respectively. $\mathrm{R}^{2}$ is the R-square of the regression, and Sig is the p-value of the coefficient estimates (i.e. GRR). The order of the countries is the ascending order of the mean.

For the Coefficient of Variation, Japan and Australia are the lowest, and Canada and Spanish secondary education are the highest. The U.S. is below the median. In addition, for the three education levels in Japan, the GRR is around zero, the $\mathrm{R}^{2}$ is very small, and $\mathrm{p}$ - value is closed to one. Thus, the Coefficients of Variation for the three levels of education have no linear trend and are very stable (very small standard deviation compared to mean). For Canada, the GRR is $0.35 \%, \mathrm{R}^{2}$ is 0.316 , and is not significant. Actually, the Coefficient of Variation increased moderately from 2000 to 2005. For the U.S., the average Coefficient of Variation is 0.218 , and is slowly decreasing at the rate of $0.2 \%$ each year.

For Gini Coefficient, Japan still has the lowest mean for three levels of education, and with no significant trends of increase or decrease. Primary and secondary educations in Australia also perform very well, with the Gini Coefficients of 0.075 and 0.082 , and significant decreasing trends. Canada and Spanish secondary education are relatively the worst in disparity. The U.S. has a mean of 0.117 , and GRR of $-0.1 \%$.

However, we must keep in mind of the limitations of Gini Coefficient when doing comparison. For a large, economically diverse country, a much higher coefficient will be calculated for the country as a whole than will be calculated for each of its regions. For this reason, the scores calculated for individual countries within the European Union (EU) are difficult to compare with the score of the entire US: the overall value for the EU should be used in that case, which is still much lower than the United States. (Note 8) Using decomposable inequality measures (e.g. the Theil index $\mathrm{T}$ converted by $1-\mathrm{e}-\mathrm{T}$ into an inequality coefficient) averts such problems. However, we cannot get local level data to calculate Theil index.

In addition, countries with similar Gini coefficients can still have very different per student public expenditure distributions. This is because the Lorenz curves can have different shapes and yet still yield the same Gini coefficient. Although the six countries we choose don't have the same value of Gini coefficient, we still double checked the shapes of Lorenz curves for each Gini coefficient series across countries.

Despite the considerations above, the relative disparity level and trend are quite consistent no matter using Coefficient of Variations or Gini Coefficient. This could be taken as a robust analysis of the disparity comparison, which enables us to continue the study below.

To capture the similarities and differences of the school funding characteristics across the six countries, we examined each country regarding the share of three levels (central, regional, and local) of government spending, intergovernmental transfer, special programs to reduce disparity, school finance formula, and trend of centralization/decentralization of school funding system. According to Tsang \& Ding (2005) intergovernmental transfer can be an effective policy tool to reduce disparity. In addition, school funding formulas accounting for student number and characteristics are commonly believed to be a basic guarantee for equal funding (Baker et al., 2007). We also examine the effects of any special programs initiated by central governments or regional governments that aiming at reducing disparities. In the end, we want to check the trend of centralization/decentralization of school funding system, because in general, centralized systems are more capable to achieve equity and decentralized systems face more difficulties to achieve this goal. It should be mentioned that the conclusion of one system is centralizing or decentralizing is based on the trends of shares of government spending across time. If the share of central government spending increases or the share of local government spending decreases, we will infer that this system is centralizing, and vice versa. Table 17 below summarized all the information we could get so far.

For the U.S. and U.K., the local government plays a major role in financing basic education. For Australia, Spain, Canada, and Japan, the regional government takes larger responsibility to finance basic education. Most of the central governments transfer most of their money for basic education to lower level of governments or schools except Spain. All the English Speaking countries and European countries have the tradition of using school funding formulas to distribute resources.

Actually the basic education systems in all the six countries are highly decentralized in terms of administration and finance. The central government in Japan has the highest share for education funding of $23 \%$ and $24 \%$ for primary 
and lower secondary education respectively, compared to the central governments in other countries. This is consistent with Japan's ranking of the lowest disparity among all the countries. Regional governments in Australia, Spain and Canada play the major role in resource mobilization and education distribution. The shares of regional government funding are all above $70 \%$. In addition, there is no clear evidence of the existence of a national level coordination to reduce education disparity in these three countries. The United States roughly equally divide the funding responsibility between regional government and local government, and the shares of education funding at these two levels are $40 \%$ and 50 respectively. The federal government's ability to eliminate disparities is also very limited. In the United Kingdom, local governments have much larger responsibilities in resource mobilization than regional governments. The share of local government funding in the UK is above $80 \%$. This fact is also consistent with the relatively high disparities among the six countries.

The definition of centralization here is that the share of central government spending increases or the share of local government spending decreases. The definition of decentralization here is that the share of central government spending decreases or the share of regional or local government spending increases. Countries with the centralization trend at certain level of education include the UK (primary education and secondary education) and Australia (primary education). Countries with the decentralization trend at certain level of education include the U.S. (primary and secondary education together), Australia (secondary education), Spain, and Canada. The trends of Japan are very stable, i.e. there is neither centralization nor decentralization.

All the six countries use funding formulas based on enrollment and special needs to allocate funding to schools. However, most of the funding formulas are at not uniform across regions within each country, except Japan. In Japan, the school funding formulas are decided at the national level. This might also be a reason for its low disparity.

\subsection{Measures for Reducing Financial Inequity: A Synthesis}

Due to the limited information and limited data analysis, the conclusions on measures of reducing disparities should be taken with some caution. Although our analysis shows some correlation between reduction in financial disparity and policy factors, it does not necessarily mean that this is a causal effect. Much research in the future is warranted.

For Japan, there is no decreasing trend of the disparity indicators, thus the main policy challenge is how to maintain a low level of disparity. Several experiences could be summarized from Japan's case study. First, the class size, number of teachers, number of officials and salaries are all calculated based on the number of students by law. This funding formula is conducted across the country. Second, both the central government and the provincial government subsidize basic education at the local level to ensure equal education opportunity. Third, $23 \%$ of total basic education revenue comes from the central government, and is distributed to regional government by intergovernmental transfer, which pays for one third of teacher salaries. In the end, the funding system is very stable. The shares of three levels of governments change within only one percent during the last decade. Overall, the Japanese school funding system is very stable, transparent, uniform, and involves a significant effort from central and provincial government. These characteristics are the key factors that keep a high level of funding equity.

Australia has the next lowest level of financial disparity; and English and the United States have somewhat higher but similar level of disparity. It may due to the tradition of the use of school funding formulas in these three countries. However, financial disparity is much higher in Spain and highest in Canada. One may speculate that the absence of central education department in Canada might be a contributing reason for the relatively large disparity of Canada. In Spain, there is also no special intergovernmental transfer for education.

Three possible explanations for the relationship between shares of government funding and expenditure disparity may be considered. First, if the share of central government funding is large enough, like in Japan, the central government could reallocate significant amount of resources to regional government and reduce disparity at regional level. Second, if the share of regional government funding is the largest among the three levels of government, such as Australia and Spain, the regional level expenditure disparity could still be controlled because regional governments have enough power to adjust per student expenditure to keep themselves not far from other regions within a country. Third, if the share of local government funding is the largest, such as England, the regional level expenditure disparity could be significant because neither the central government nor the regional government could have influential impacts on the local government to achieve lower disparity even just at regional level, not to say at local level.

With respect to the relationship between the trend of centralization/decentralization and the trend of financial disparity, a consistent pattern appears: a centralization trend is accompanied by decreasing disparity. The secondary education in Australia has a decentralizing financial system, and its disparity decreasing rate measured by GRR is smaller and less significant than that of primary education. For Japan, stable shares of expenditures go with stable trends of disparities. 
To summarize, countries with a significant share of central government or regional government funding, nationally uniform school funding formulas and/or a significant share of intergovernmental transfer are more likely to have a higher level of funding equity. A centralization trend is associated with decreasing financial disparity.

\section{Conclusions and Further Research}

Generally speaking, among the six populous OECD countries with an education finance system involving more than one level of government, Japan and Australia achieve the highest level of equity in regards to public spending on public compulsory education, and Canada and Spain have the highest disparity indicators. The United Kingdom and the United States are in between. During the period of the late 1990s and the early 2000s, financial disparities (and thus horizontal inequity) had a decreasing trend in most of the cases in these six countries. This decreasing trend was related to a variety of different government finance policies in these countries. The basic finding is that a larger share of central or regional government funding relative to the share of local government funding, a significant amount of intergovernmental transfer, and nationally uniform school funding formulas appear to be contributing factors for a higher level of financial equity in basic education. And a move towards financial centralization at the central or regional level may also be associated with decreasing financial disparity.

This research has several limitations which may be addressed in future studies. First, due to difficulty in access to information, the disparity indicators are calculated using data at regional level (Note 9), which omits a large share of disparities within each region. There are also large disparities at the local level and school level which are not documented and analyzed here. Second, this research considers only public expenditures on public institutions. Private expenditure and private education may also be important factors influencing disparities in basic education. Third, this research demonstrates some correlating patterns between financial disparities and government financing policies and characteristics; more detailed analysis with better data are needed to draw more definite causal inferences. Finally, this research only examines education equity through measures in funding disparities, but does not connect funding with student outcomes. There is no analysis of how financial resources are utilized and whether resources are efficiently used to produce desired education outcomes.

\section{References}

Australia Ministerial Council on Education, Employment, Training and Youth Affairs. Resourcing the National Goals for Schooling: An Agreed Framework of Principles for Funding Schools.

Baker, B., Green, P., \& Richards, C. (2007). Financing Education Systems Prentice Hall, New Jersey.

Carbonell, J., \& Alcalde, A. (2008). Fiscal Equation in Spain. In: Bosch, N., \& Duran J. (Eds.), Fiscal Federalism and Political Decentralization (pp. 147-168). Massachusetts: Edward Elgar Publishing, Inc.

Cohn, E., \& Geske, T. (1990). Economics of Education, (3rd ed.). Mason: South-Western College Publishing, (Chapter 11).

Guthrie, J., \& Rothstein, R. (1999). Enabling adequacy to achieve reality: Translating adequacy into state school finance distribution arrangements. In: Ladd, H., \& Chalk, R. (Eds.), Equity and adequacy in education finance. (pp. 209-259). Washington, DC: National Academy Press.

Hanson, E. M. (1995). Best (and Worst) Practices in Educational Decentralization: The Cases of Venezuela, Colombia, Argentina, and Spain. Paper presented at the World Bank Seminar on Education Decentralization, June 2. World Bank, Human Development Department, Washington, D.C.

Simkins, T. (2003). School finance and equity in England: an analysis of strategies and consequences. Presented at the Annual Meeting of the American Educational Research Association, Chicago.

Tsang, M., \& Ding, Y. (2007). The role of intergovernmental grants in decentralized financing of compulsory education in China. In: Tsang, M., et. al. (Eds.), The financial reform of compulsory education in China. New York: Center on Chinese Education, Teachers College Columbia University.

Tsang, M., \& Ding, Y. (2005). Resource utilization and financial disparities in compulsory education in China. China Review, 5(1), 1-31

Tsang, M., Mizunoya, S., Zhang, Y., \& You, Y. (2008, Unpublished results) Financial disparities in primary and secondary education: A cross-national study. New York, USA: Center on Chinese Education, Teachers College Columbia University.

Weiler, H. (1990). Comparative Perspectives on Educational Decentralization: An Exercise in Contradiction? Educational Evaluation and Policy Analysis, 12(4), 433-448. doi:10.2307/1164476, http://dx.doi.org/10.2307/1164476 
Yinger, J. (2004). State Aid and the Pursuit of Educational Equity: An Overview. In Yinger, J. (Eds), In Helping Children Left Behind: State Aid and the Pursuit of Educational Equity (pp. 3-57). Massachusetts: MIT Press.

\section{Notes}

Note 1. For details on socio-economic-political background, educational development, and the system of education fiancé for each of the six countries, please refer to: Tsang, M., Mizunoya, S., Zhang, Y., \& You, Y. (2008). Financial disparities in primary and secondary education: Case studies of OECD countries with decentralized school finance. New York, NY: Research Monograph 2008-1, Center on Chinese Education, Teachers College Columbia University.

Note 2. Quoted from U.S. department of Education

Note 3. http://www.edutopia.org/economic-stimulus-education-school-budget

Note 4. OECD data include the total amount of the transfer from Central government to Regional and Local government, as well as the total amount of transfer from Regional government to Local government. However, it is not clear how much of these transfers are spent only for direct expenditures for public institutions. The transfer for the direct public expenditure was estimated by multiplying the ratio of "Direct Public Education Expenditures for Public Schools" to "Total Direct Expenditures", which is the ratio of the public expenditure to the total expenditures excluding the transfer budget, with the total amount of transfer.

Note 5. Transfers showed earlier sections of this paper seem to refer NTD only. In 2004 OECD data, the total transfer to compulsory education is 2,905 billion yen and NTD of 2004 is 2,547 billion yen. In order to reconcile two datasets, a further study is needed.

Note 6. http://www.mext.go.jp/a_menu/shotou/gimukyoiku/outline/001/008.htm The laws are in Japanese, and are translated by the authors.

Note 7. Backer et al. 2008

Note 8. CIA World Factbook

Note 9. The disparity indicators for England are calculated using data at local government level.

Table 1. Socio-economic Indicators of Countries (2006)

\begin{tabular}{lcccccc}
\hline \multicolumn{1}{c}{ Indicators } & Australia & Canada & Japan & Spain & $\begin{array}{c}\text { United } \\
\text { Kingdom }\end{array}$ & $\begin{array}{c}\text { United } \\
\text { States }\end{array}$ \\
& 0.965 & 0.967 & 0.956 & 0.949 & 0.942 & 0.950 \\
HDI $^{*}$ & 81.0 & 80.4 & 82.4 & 80.7 & 79.2 & 78.0 \\
Life expectancy at birth (years) & 35,453 & 36,813 & 31,919 & 29,382 & 32,990 & 43,801 \\
GDP per capita (PPP US\$) & 0.993 & 0.991 & 0.946 & 0.987 & 0.97 & 0.971 \\
Education index & 20.3 & 32.6 & 127.8 & 45.5 & 60.5 & 299.1 \\
Population_(millions) & 0.352 & 0.326 & 0.249 & 0.347 & 0.36 & 0.408 \\
Gini index & 34.0 & 38.6 & 36.5 & 38.8 & 44.6 & 37.4 \\
Gov. Spending as \%GDP & & & & &
\end{tabular}

*HDI: Human Development Index

** 2007 Data

Data source: Human Development Report 2007/2008, OECD dataset 
Table 2. Indicators of Educational Development (2006)

\begin{tabular}{|c|c|c|c|c|c|c|c|}
\hline & & Australia & Canada & Japan & Spain & $\begin{array}{c}\text { United } \\
\text { Kingdom }\end{array}$ & $\begin{array}{l}\text { United } \\
\text { States }\end{array}$ \\
\hline \multirow{5}{*}{ 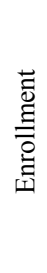 } & Primary & 1936189 & 2342189 & 7229135 & 2501205 & 4508105 & 24319033 \\
\hline & Lower secondary & 1022480 & 843933 & 3653844 & 1853423 & 2285601 & 13051497 \\
\hline & Upper secondary & 510481 & 1911134 & 3723879 & 901906 & 3207711.9 & 11500820 \\
\hline & Secondary education & 1532961 & 2755067 & 7377723 & 2755329 & 5493312.9 & 24552317 \\
\hline & Primary and secondary & 3469150 & 5097256 & 14606858 & 5256534 & 10001418 & 48871351 \\
\hline \multirow{5}{*}{ 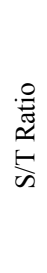 } & Primary & N.A. & N.A. & 18.71 & 13.58 & 18.04 & 13.81 \\
\hline & Lower secondary & N.A. & N.A. & 14.10 & 6.57 & 15.52 & 14.16 \\
\hline & Upper secondary & N.A. & N.A. & 10.63 & N.A. & 9.00 & 15.17 \\
\hline & Secondary & N.A. & N.A. & 12.10 & 9.76 & 10.90 & 14.62 \\
\hline & Primary and secondary & N.A. & 14.99 & 14.67 & 11.27 & 13.27 & 14.20 \\
\hline \multirow{2}{*}{ 蕞 } & Primary & $97 \%$ & $99 \%$ & $100 \%$ & $99 \%$ & $99 \%$ & $92 \%$ \\
\hline & Secondary & $86 \%$ & N.A. & $100 \%$ & $98 \%$ & $95 \%$ & $89 \%$ \\
\hline \multirow{2}{*}{ 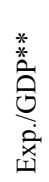 } & $\begin{array}{c}\text { Primary, secondary, and post } \\
\text { secondary non-tertiary }\end{array}$ & $3.5 \%$ & M & $2.7 \%$ & $2.8 \%$ & $3.8 \%$ & $3.7 \%$ \\
\hline & Total all levels & $4.3 \%$ & M & $3.5 \%$ & $4.2 \%$ & $5.0 \%$ & $5.1 \%$ \\
\hline
\end{tabular}

* NER: Net Enrollment Rate, 2005 data.

** Education Expenditure as \% GDP, 2005 data.

Data source: Human Development Report 2007/2008, OECD dataset

Table 3. Trends of Financial Disparity Indicators for K-12 Education - the U.S.

\begin{tabular}{|c|c|c|c|c|c|c|c|c|c|c|c|c|c|}
\hline & 1993 & 1994 & 1995 & 1996 & 1997 & 1998 & 1999 & 2000 & 2001 & 2002 & 2003 & 2004 & 2005 \\
\hline Restricted Range $^{*}$ & 5506 & 5419 & 5207 & 4970 & 4448 & 4423 & 4248 & 4062 & 3993 & 4428 & 4605 & 5120 & 5260 \\
\hline Federal Ratio & 2.18 & 2.09 & 2.03 & 1.96 & 1.83 & 1.81 & 1.72 & 1.69 & 1.64 & 1.69 & 1.72 & 1.8 & 1.8 \\
\hline Coefficient of Variation & 0.244 & 0.247 & 0.229 & 0.224 & 0.211 & 0.203 & 0.203 & 0.201 & 0.2 & 0.215 & 0.218 & 0.218 & 0.223 \\
\hline Gini Coefficient & 0.131 & 0.131 & 0.123 & 0.121 & 0.115 & 0.11 & 0.109 & 0.108 & 0.108 & 0.114 & 0.117 & 0.118 & 0.12 \\
\hline
\end{tabular}

Source: Public Education Finances from 1993 to 2005, National Center for Education Statistics; Authors' calculation

*Three highest and three lowest provinces are excluded as an approximation to exclude all the observations below $5 \%$ and above $95 \%$. 
Table 4. Share of Public Funding Source for Public Primary and Secondary Education by Levels of Government the U.S.

\begin{tabular}{|c|c|c|c|c|c|c|c|c|c|c|c|}
\hline & $\begin{array}{c}\text { Gov. } \\
\text { Level }\end{array}$ & 1997 & 1998 & 1999 & 2000 & 2001 & 2002 & 2003 & 2004 & 2005 & 2006 \\
\hline \multirow{3}{*}{$\begin{array}{c}\text { After } \\
\text { transfer }\end{array}$} & Central & $0.74 \%$ & $0.73 \%$ & $0.69 \%$ & $0.68 \%$ & $0.55 \%$ & $0.53 \%$ & $0.57 \%$ & $0.54 \%$ & $0.56 \%$ & $0.48 \%$ \\
\cline { 2 - 10 } & Region & $0.76 \%$ & $0.73 \%$ & $0.73 \%$ & $0.77 \%$ & $0.81 \%$ & $0.85 \%$ & $0.88 \%$ & $0.90 \%$ & $0.90 \%$ & $0.92 \%$ \\
\hline \multirow{3}{*}{$\begin{array}{c}\text { Before } \\
\text { transfer }\end{array}$} & Lecal & $98.51 \%$ & $98.54 \%$ & $98.57 \%$ & $98.55 \%$ & $98.64 \%$ & $98.62 \%$ & $98.54 \%$ & $98.56 \%$ & $98.53 \%$ & $98.60 \%$ \\
\cline { 2 - 11 } & Region & $50.00 \%$ & $50.36 \%$ & $50.73 \%$ & $51.48 \%$ & $41.73 \%$ & $41.64 \%$ & $41.28 \%$ & $39.20 \%$ & $39.19 \%$ & $38.60 \%$ \\
\hline
\end{tabular}

Source: OECD, authors' own calculation.

Table 5. Trends of Disparity Indicators - England

\begin{tabular}{|c|c|c|c|c|c|c|c|c|c|}
\hline Years & 1996 & 1997 & 1998 & 1999 & 2000 & 2001 & 2002 & 2003 & 2004 \\
\hline Restricted Range & 2385 & 2289 & 2249 & 1984 & 1662 & 1796 & 2041 & 1724 & 2108 \\
\hline Federal Range Ratio & 1.703 & 1.711 & 1.737 & 1.630 & 1.539 & 1.559 & 1.603 & 1.516 & 1.587 \\
\hline Coefficient of Variation & 0.287 & 0.303 & 0.303 & 0.209 & 0.237 & 0.187 & 0.177 & 0.206 & 0.189 \\
\hline Gini Coefficient & 0.107 & 0.108 & 0.104 & 0.085 & 0.078 & 0.073 & 0.074 & 0.081 & 0.080 \\
\hline
\end{tabular}

Data source: UK National Statistics, Department of Children, Schools and Families, authors' calculation. All monetary figures are in 2004 value.

Table 6. Share of Public Funding Source for Public Schools by Levels of Government by Levels of Education - UK

\begin{tabular}{|c|c|c|c|c|c|c|c|c|c|}
\hline & $\begin{array}{c}\text { Gov. } \\
\text { Level }\end{array}$ & 1997 & 1998 & 1999 & 2000 & 2001 & 2002 & 2003 & 2004 \\
\hline \multirow{2}{*}{$\begin{array}{c}\text { Before } \\
\text { Transfer }\end{array}$} & Central & $8.02 \%$ & $12.93 \%$ & $7.89 \%$ & $6.98 \%$ & $12.30 \%$ & $10.16 \%$ & $10.79 \%$ & $16.98 \%$ \\
\cline { 2 - 10 } & Local & $91.98 \%$ & $87.07 \%$ & $92.11 \%$ & $93.02 \%$ & $87.70 \%$ & $89.84 \%$ & $89.21 \%$ & $83.02 \%$ \\
\hline \multirow{2}{*}{$\begin{array}{c}\text { After } \\
\text { Transfer }\end{array}$} & Central & $4.29 \%$ & $6.57 \%$ & $3.95 \%$ & $4.45 \%$ & $5.92 \%$ & $4.27 \%$ & $4.12 \%$ & $11.56 \%$ \\
\cline { 2 - 10 } & Local & $95.71 \%$ & $93.43 \%$ & $96.05 \%$ & $95.55 \%$ & $94.08 \%$ & $95.73 \%$ & $95.88 \%$ & $88.44 \%$ \\
\hline
\end{tabular}

Data source: OECD, authors' calculation.

Note: The regional government does not have any share in government expenditure in UK, thus it is not listed in the table. 
Table 7. Trends of Disparity Indicators - Australia*

\begin{tabular}{|c|c|c|c|c|c|c|c|c|c|}
\hline & Year & 1999 & 2000 & 2001 & 2002 & 2003 & 2004 & 2005 & 2006 \\
\hline \multirow{4}{*}{ Primary } & Restricted Range & 1583 & 1563 & 892 & 500 & 723 & 2288 & 1880 & 1447 \\
\cline { 2 - 9 } & Federal Range Ratio & 1.219 & 1.209 & 1.116 & 1.055 & 1.079 & 1.246 & 1.194 & 1.139 \\
\cline { 2 - 9 } & Coefficient of Variation & 0.194 & 0.209 & 0.181 & 0.209 & 0.161 & 0.156 & 0.134 & 0.137 \\
\cline { 2 - 9 } & Gini Coefficient & 0.085 & 0.088 & 0.076 & 0.078 & 0.065 & 0.076 & 0.068 & 0.064 \\
\hline \multirow{5}{*}{ Secondary } & Restricted Range & 1424 & 1190 & 2247 & 1608 & 1899 & 3299 & 2783 & 2568 \\
\cline { 2 - 9 } & Federal Range Ratio & 1.143 & 1.123 & 1.230 & 1.145 & 1.166 & 1.286 & 1.229 & 1.204 \\
\cline { 2 - 9 } & Coefficient of Variation & 0.233 & 0.205 & 0.191 & 0.229 & 0.177 & 0.163 & 0.147 & 0.174 \\
\cline { 2 - 9 } & Gini Coefficient & 0.089 & 0.082 & 0.081 & 0.089 & 0.081 & 0.080 & 0.072 & 0.079 \\
\hline
\end{tabular}

Source: The Ministerial Council on Education, Employment, Training and Youth Affairs (MCEETYA), National Schools Statistics Collection (NSSC), 2005 (Draft - unpublished), authors' calculation. All monetary figures are in 2006 value.

*Figures are constant figures.

Table 8. Share of Public Expenditure by Levels of Education and Government - Australia

\begin{tabular}{|c|c|c|c|c|c|c|c|c|c|c|c|c|}
\hline $\begin{array}{c}\text { Education } \\
\text { Level }\end{array}$ & & $\begin{array}{l}\text { Gov. } \\
\text { Level }\end{array}$ & 1997 & 1998 & 1999 & 2000 & 2001 & 2002 & 2003 & 2004 & 2005 & 2006 \\
\hline \multirow{4}{*}{ Primary } & \multirow{2}{*}{$\begin{array}{c}\text { After } \\
\text { transfer }\end{array}$} & Central & $0.00 \%$ & $0.44 \%$ & $0.45 \%$ & $0.38 \%$ & $0.47 \%$ & $0.50 \%$ & $0.56 \%$ & $0.62 \%$ & $0.59 \%$ & $0.55 \%$ \\
\hline & & Region & $100.00 \%$ & $99.56 \%$ & $99.55 \%$ & $99.62 \%$ & $99.53 \%$ & $99.50 \%$ & $99.44 \%$ & $99.38 \%$ & $99.41 \%$ & $99.45 \%$ \\
\hline & \multirow{2}{*}{$\begin{array}{l}\text { Before } \\
\text { transfer }\end{array}$} & Central & $13.10 \%$ & $12.45 \%$ & $14.51 \%$ & $14.72 \%$ & $15.24 \%$ & $16.09 \%$ & $16.64 \%$ & $17.96 \%$ & $17.04 \%$ & $17.60 \%$ \\
\hline & & Region & $86.90 \%$ & $87.55 \%$ & $85.49 \%$ & $85.28 \%$ & $84.76 \%$ & $83.91 \%$ & $83.36 \%$ & $82.04 \%$ & $82.96 \%$ & $82.40 \%$ \\
\hline \multirow{4}{*}{ Secondary } & \multirow{2}{*}{$\begin{array}{c}\text { After } \\
\text { transfer }\end{array}$} & Central & $10.67 \%$ & $8.73 \%$ & $7.74 \%$ & $7.68 \%$ & $7.97 \%$ & $8.13 \%$ & $8.13 \%$ & $8.10 \%$ & $8.45 \%$ & $9.16 \%$ \\
\hline & & Region & $89.33 \%$ & $91.27 \%$ & $92.26 \%$ & $92.32 \%$ & $92.03 \%$ & $91.87 \%$ & $91.87 \%$ & $91.90 \%$ & $91.55 \%$ & $90.84 \%$ \\
\hline & \multirow{2}{*}{$\begin{array}{l}\text { Before } \\
\text { transfer }\end{array}$} & Central & $19.95 \%$ & $17.68 \%$ & $14.68 \%$ & $14.33 \%$ & $14.87 \%$ & $14.97 \%$ & $14.86 \%$ & $15.21 \%$ & $14.65 \%$ & $16.00 \%$ \\
\hline & & Region & $80.05 \%$ & $82.32 \%$ & $85.32 \%$ & $85.67 \%$ & $85.13 \%$ & $85.03 \%$ & $85.14 \%$ & $84.79 \%$ & $85.35 \%$ & $84.00 \%$ \\
\hline
\end{tabular}

Data source: OECD, authors' calculation

Note: The local government does not have any share in government expenditure in Australia, thus is not list in the table. 
Table 9. Trends of Disparity Indicators - Spain

\begin{tabular}{|l|l|c|c|c|c|c|c|}
\hline & & 2000 & 2001 & 2002 & 2003 & 2004 & 2005 \\
\hline \multirow{4}{*}{$\begin{array}{c}\text { Pre-school and } \\
\text { Primary School }\end{array}$} & Restricted Range & 1587 & 1254 & 1364 & 1457 & 1508 & 1442 \\
\cline { 2 - 8 } & Federal Range Ratio & 1.81 & 1.61 & 1.67 & 1.75 & 1.75 & 1.69 \\
\cline { 2 - 8 } & Coefficient of Variation & 0.293 & 0.194 & 0.199 & 0.207 & 0.194 & 0.182 \\
\cline { 2 - 8 } & Gini Coefficient & 0.139 & 0.102 & 0.105 & 0.110 & 0.106 & 0.098 \\
\hline \multirow{3}{*}{ Secondary School } & Restricted Range & 4273 & 3933 & 3632 & 3859 & 3914 & 3700 \\
\cline { 2 - 8 } & Federal Range Ratio & 2.25 & 1.91 & 1.79 & 1.81 & 1.80 & 1.73 \\
\cline { 2 - 8 } & Coefficient of Variation & 0.310 & 0.272 & 0.251 & 0.251 & 0.233 & 0.233 \\
\cline { 2 - 8 } & Gini Coefficient & 0.159 & 0.132 & 0.124 & 0.123 & 0.116 & 0.114 \\
\hline
\end{tabular}

Source: Authors calculation based on Gast Publico 2000-2005 and Estadística Enseñanzas no Universitarias Resultados Detallados - Curso from 1999-2000 to 2004-2005. All monetary figures are in 2005 value.

Table 10. Average Share of Public Education Funding Source for Public Schools by the Levels of Education and Government*

\begin{tabular}{|c|c|c|c|c|c|c|c|c|c|c|c|c|}
\hline $\begin{array}{c}\text { Education } \\
\text { Level }\end{array}$ & & Gov. Level & 1997 & 1998 & 1999 & 2000 & 2001 & 2002 & 2003 & 2004 & 2005 & 2006 \\
\hline \multirow{6}{*}{ Primary } & \multirow{3}{*}{$\begin{array}{l}\text { After } \\
\text { transfer }\end{array}$} & Central & $40.04 \%$ & $38.92 \%$ & $32.34 \%$ & $14.16 \%$ & $13.54 \%$ & $12.73 \%$ & $11.81 \%$ & $12.54 \%$ & $12.30 \%$ & $11.60 \%$ \\
\hline & & Region & $49.68 \%$ & $49.47 \%$ & $57.61 \%$ & $76.06 \%$ & $75.53 \%$ & $76.97 \%$ & $75.78 \%$ & $75.21 \%$ & $76.00 \%$ & $76.63 \%$ \\
\hline & & Local & $10.28 \%$ & $11.62 \%$ & $10.04 \%$ & $9.78 \%$ & $10.94 \%$ & $10.29 \%$ & $12.41 \%$ & $12.25 \%$ & $11.71 \%$ & $11.76 \%$ \\
\hline & \multirow{3}{*}{$\begin{array}{l}\text { Before } \\
\text { transfer }\end{array}$} & Central & $40.04 \%$ & $38.92 \%$ & $32.34 \%$ & $14.16 \%$ & $13.54 \%$ & $12.73 \%$ & $11.81 \%$ & $12.54 \%$ & $12.30 \%$ & $11.95 \%$ \\
\hline & & Region & $49.68 \%$ & $49.47 \%$ & $57.61 \%$ & $76.06 \%$ & $75.53 \%$ & $76.97 \%$ & $75.78 \%$ & $75.21 \%$ & $76.00 \%$ & $76.29 \%$ \\
\hline & & Local & $10.28 \%$ & $11.62 \%$ & $10.04 \%$ & $9.78 \%$ & $10.94 \%$ & $10.29 \%$ & $12.41 \%$ & $12.25 \%$ & $11.71 \%$ & $11.76 \%$ \\
\hline \multirow{6}{*}{ Secondary } & \multirow{3}{*}{$\begin{array}{l}\text { After } \\
\text { transfer }\end{array}$} & Central & $47.17 \%$ & $44.71 \%$ & $36.61 \%$ & $21.02 \%$ & $21.56 \%$ & $20.27 \%$ & $13.99 \%$ & $12.39 \%$ & $11.67 \%$ & $12.12 \%$ \\
\hline & & Region & $48.48 \%$ & $51.02 \%$ & $59.46 \%$ & $75.23 \%$ & $75.38 \%$ & $76.19 \%$ & $83.00 \%$ & $84.64 \%$ & $85.16 \%$ & $84.77 \%$ \\
\hline & & Local & $4.35 \%$ & $4.27 \%$ & $3.92 \%$ & $3.75 \%$ & $3.06 \%$ & $3.53 \%$ & $3.01 \%$ & $2.97 \%$ & $3.17 \%$ & $3.10 \%$ \\
\hline & \multirow{3}{*}{$\begin{array}{l}\text { Before } \\
\text { transfer }\end{array}$} & Central & $47.17 \%$ & $44.71 \%$ & $36.61 \%$ & $21.02 \%$ & $21.56 \%$ & $20.27 \%$ & $13.99 \%$ & $12.39 \%$ & $11.67 \%$ & $12.77 \%$ \\
\hline & & Region & $48.48 \%$ & $51.02 \%$ & $59.46 \%$ & $75.23 \%$ & $75.38 \%$ & $76.19 \%$ & $83.00 \%$ & $84.64 \%$ & $85.16 \%$ & $84.13 \%$ \\
\hline & & Local & $4.35 \%$ & $4.27 \%$ & $3.92 \%$ & $3.75 \%$ & $3.06 \%$ & $3.53 \%$ & $3.01 \%$ & $2.97 \%$ & $3.17 \%$ & $3.10 \%$ \\
\hline
\end{tabular}

Source: OECD, authors' calculation.

*For Lower secondary, the data of 1998 is missing. Upper secondary data is only for 1997 and 1998. 
Table 11. Trends of Disparity Indicators - Canada

\begin{tabular}{lcccccccc}
\hline Year & 1998 & 1999 & 2000 & 2001 & 2002 & 2003 & 2004 & 2005 \\
Restricted Range & 7150 & 6059 & 6452 & 5960 & 7631 & 8762 & 9054 & 9053 \\
Federal Range Ratio & 2.228 & 1.952 & 2.021 & 1.934 & 2.133 & 2.333 & 2.316 & 2.280 \\
Coefficient of Variation & 0.325 & 0.274 & 0.282 & 0.283 & 0.320 & 0.335 & 0.336 & 0.324 \\
Gini Coefficient & 0.163 & 0.135 & 0.138 & 0.142 & 0.156 & 0.163 & 0.163 & 0.157 \\
\hline
\end{tabular}

Data Source: Education Indicators in Canada 2008, calculated by authors. All monetary figures are in 2005 value.

Table 12. Share of Funding Source for Public Schools by Level of Government for Elementary and Secondary Education Level from 1997 to 2003

\begin{tabular}{|c|c|c|c|c|c|c|c|c|c|}
\hline & & 1997 & 1998 & 1999 & 2000 & 2001 & 2003 & 2005 & 2006 \\
\hline \multirow{3}{*}{$\begin{array}{c}\text { Before } \\
\text { transfer }\end{array}$} & Federal & $3.55 \%$ & $3.68 \%$ & $3.39 \%$ & $3.26 \%$ & $3.33 \%$ & $2.86 \%$ & $3.35 \%$ & $3.03 \%$ \\
\cline { 2 - 9 } & Legional & $10.88 \%$ & $7.66 \%$ & $7.54 \%$ & $8.31 \%$ & $8.24 \%$ & $7.91 \%$ & $7.99 \%$ & $8.00 \%$ \\
\hline \multirow{3}{*}{$\begin{array}{c}\text { After } \\
\text { transfer }\end{array}$} & Regional & $85.57 \%$ & $88.66 \%$ & $89.07 \%$ & $88.43 \%$ & $88.43 \%$ & $89.24 \%$ & $88.66 \%$ & $88.97 \%$ \\
\cline { 2 - 10 } & Regional & $4.35 \%$ & $4.17 \%$ & $4.19 \%$ & $4.14 \%$ & $4.46 \%$ & $3.71 \%$ & $4.21 \%$ & $3.98 \%$ \\
\cline { 2 - 10 } & Local & $34.98 \%$ & $33.74 \%$ & $28.17 \%$ & $26.15 \%$ & $27.33 \%$ & $26.06 \%$ & $26.15 \%$ & $25.42 \%$ \\
\hline
\end{tabular}

Source: OECD, authors' calculation. Data in 2002 and 2004 are unavailable. 
Table 13. Trends of Disparity Indicators - Japan

\begin{tabular}{|c|c|c|c|c|c|c|c|c|}
\hline & & 1998 & 1999 & 2000 & 2001 & 2002 & 2003 & 2004 \\
\hline \multirow{4}{*}{ Primary } & Restricted Range & 323567 & 333119 & 343149 & 287572 & 304719 & 314488 & 334466 \\
\hline & Federal Range Ratio & 1.44 & 1.45 & 1.45 & 1.36 & 1.38 & 1.4 & 1.43 \\
\hline & $\begin{array}{l}\text { Coefficient of } \\
\text { Variation }\end{array}$ & 0.112 & 0.12 & 0.12 & 0.115 & 0.111 & 0.122 & 0.115 \\
\hline & Gini Coefficient & 0.062 & 0.067 & 0.067 & 0.063 & 0.062 & 0.067 & 0.063 \\
\hline \multirow{4}{*}{$\begin{array}{l}\text { Lower } \\
\text { Secondary }\end{array}$} & Restricted Range & 404924 & 403442 & 325722 & 377752 & 325121 & 357413 & 373103 \\
\hline & Federal Range Ratio & 1.51 & 1.5 & 1.39 & 1.43 & 1.36 & 1.39 & 1.4 \\
\hline & $\begin{array}{l}\text { Coefficient of } \\
\text { Variation }\end{array}$ & 0.115 & 0.12 & 0.112 & 0.11 & 0.1 & 0.122 & 0.118 \\
\hline & Gini Coefficient & 0.06 & 0.063 & 0.059 & 0.057 & 0.053 & 0.06 & 0.059 \\
\hline \multirow{4}{*}{$\begin{array}{c}\text { Upper } \\
\text { Secondary }\end{array}$} & Restricted Range & 430175 & 385000 & 328216 & 386437 & 402269 & 388394 & 357140 \\
\hline & Federal Range Ratio & 1.46 & 1.43 & 1.35 & 1.4 & 1.41 & 1.4 & 1.38 \\
\hline & $\begin{array}{l}\text { Coefficient of } \\
\text { Variation }\end{array}$ & 0.12 & 0.11 & 0.102 & 0.118 & 0.117 & 0.115 & 0.106 \\
\hline & Gini Coefficient & 0.063 & 0.061 & 0.057 & 0.066 & 0.065 & 0.064 & 0.059 \\
\hline
\end{tabular}

Source: Ministry of Internal Affairs and Communication, authors' own calculation. All monetary figures are in 2004 value. 
Table 14. Share of Education Funding for Public Schools by Level of Education and Government - Japan

\begin{tabular}{|c|c|c|c|c|c|c|c|c|c|c|c|c|}
\hline $\begin{array}{c}\text { Education } \\
\text { Level }\end{array}$ & & $\begin{array}{l}\text { Gov. } \\
\text { Level }\end{array}$ & 1997 & 1998 & 1999 & 2000 & 2001 & 2002 & 2003 & 2004 & 2005 & 2006 \\
\hline \multirow{6}{*}{ Primary } & \multirow{3}{*}{$\begin{array}{l}\text { After } \\
\text { transfer }\end{array}$} & Central & $0.38 \%$ & $0.35 \%$ & $0.37 \%$ & $0.41 \%$ & $0.37 \%$ & $0.38 \%$ & $0.36 \%$ & $0.41 \%$ & $0.38 \%$ & $0.41 \%$ \\
\hline & & Region & $74.79 \%$ & $75.35 \%$ & $75.53 \%$ & $75.78 \%$ & $75.39 \%$ & $75.63 \%$ & $75.97 \%$ & $76.53 \%$ & $76.75 \%$ & $76.74 \%$ \\
\hline & & Local & $24.82 \%$ & $24.30 \%$ & $24.10 \%$ & $23.81 \%$ & $24.25 \%$ & $23.99 \%$ & $23.67 \%$ & $23.07 \%$ & $22.87 \%$ & $22.85 \%$ \\
\hline & \multirow{3}{*}{$\begin{array}{l}\text { Before } \\
\text { transfer }\end{array}$} & Central & $30.85 \%$ & $30.91 \%$ & $31.44 \%$ & $31.73 \%$ & $31.51 \%$ & $31.66 \%$ & $31.63 \%$ & $29.90 \%$ & $27.81 \%$ & $23.32 \%$ \\
\hline & & Region & $44.33 \%$ & $44.79 \%$ & $44.46 \%$ & $44.47 \%$ & $44.25 \%$ & $44.35 \%$ & $44.70 \%$ & $47.04 \%$ & $49.31 \%$ & $53.83 \%$ \\
\hline & & Local & $24.82 \%$ & $24.30 \%$ & $24.10 \%$ & $23.81 \%$ & $24.25 \%$ & $23.99 \%$ & $23.67 \%$ & $23.07 \%$ & $22.87 \%$ & $22.85 \%$ \\
\hline \multirow{6}{*}{$\begin{array}{c}\text { Lower } \\
\text { Secondary }\end{array}$} & \multirow{3}{*}{$\begin{array}{l}\text { After } \\
\text { transfer }\end{array}$} & Central & $0.62 \%$ & $0.54 \%$ & $0.56 \%$ & $0.60 \%$ & $0.59 \%$ & $0.63 \%$ & $0.58 \%$ & $0.69 \%$ & $0.63 \%$ & $0.66 \%$ \\
\hline & & Region & $77.37 \%$ & $77.28 \%$ & $77.49 \%$ & $77.91 \%$ & $77.41 \%$ & $77.35 \%$ & $77.51 \%$ & $78.08 \%$ & $78.22 \%$ & $78.16 \%$ \\
\hline & & Local & $22.01 \%$ & $22.19 \%$ & $21.95 \%$ & $21.49 \%$ & $22.00 \%$ & $22.03 \%$ & $21.91 \%$ & $21.24 \%$ & $21.14 \%$ & $21.17 \%$ \\
\hline & \multirow{3}{*}{$\begin{array}{l}\text { Before } \\
\text { transfer }\end{array}$} & Central & $32.09 \%$ & $31.71 \%$ & $32.40 \%$ & $32.86 \%$ & $32.68 \%$ & $32.84 \%$ & $32.46 \%$ & $30.61 \%$ & $28.86 \%$ & $24.49 \%$ \\
\hline & & Region & $45.90 \%$ & $46.10 \%$ & $45.65 \%$ & $45.65 \%$ & $45.32 \%$ & $45.13 \%$ & $45.63 \%$ & $48.15 \%$ & $50.00 \%$ & $54.34 \%$ \\
\hline & & Local & $22.01 \%$ & $22.19 \%$ & $21.95 \%$ & $21.49 \%$ & $22.00 \%$ & $22.03 \%$ & $21.91 \%$ & $21.24 \%$ & $21.14 \%$ & $21.17 \%$ \\
\hline \multirow{6}{*}{$\begin{array}{c}\text { Upper } \\
\text { Secondary }\end{array}$} & \multirow{3}{*}{$\begin{array}{l}\text { After } \\
\text { transfer }\end{array}$} & Central & $0.43 \%$ & $0.40 \%$ & $0.40 \%$ & $0.44 \%$ & $0.43 \%$ & $0.40 \%$ & $0.39 \%$ & $0.42 \%$ & $0.42 \%$ & $0.47 \%$ \\
\hline & & Region & $94.13 \%$ & $93.88 \%$ & $94.02 \%$ & 93.97\% & $93.77 \%$ & $94.02 \%$ & $93.73 \%$ & $93.50 \%$ & $93.39 \%$ & $93.11 \%$ \\
\hline & & Local & $5.44 \%$ & $5.73 \%$ & $5.57 \%$ & $5.59 \%$ & $5.80 \%$ & $5.58 \%$ & $5.87 \%$ & $6.09 \%$ & $6.18 \%$ & $6.42 \%$ \\
\hline & \multirow{3}{*}{$\begin{array}{l}\text { Before } \\
\text { transfer }\end{array}$} & Central & $4.34 \%$ & $4.11 \%$ & $4.15 \%$ & $4.09 \%$ & $3.64 \%$ & $3.57 \%$ & $3.67 \%$ & $3.62 \%$ & $3.42 \%$ & $2.99 \%$ \\
\hline & & Region & $90.22 \%$ & $90.17 \%$ & $90.28 \%$ & $90.32 \%$ & $90.56 \%$ & $90.86 \%$ & $90.45 \%$ & $90.30 \%$ & $90.40 \%$ & $90.60 \%$ \\
\hline & & Local & $5.44 \%$ & $5.73 \%$ & $5.57 \%$ & $5.59 \%$ & $5.80 \%$ & $5.58 \%$ & $5.87 \%$ & $6.09 \%$ & $6.18 \%$ & $6.42 \%$ \\
\hline
\end{tabular}

Source: OECD, authors' own calculation. 
Table 15. Basic Statistics and GRR of Coefficient of Variation

\begin{tabular}{lcccccc}
\hline Country - Education level & $\mathrm{N}$ & Mean & Std. Deviation & GRR & $\mathrm{R}^{2}$ & P-value \\
Japan - Upper Secondary & 7 & 0.113 & 0.0067 & $-0.10 \%$ & 0.038 & 0.675 \\
Japan - Lower Secondary & 7 & 0.114 & 0.0074 & $0.00 \%$ & 0.000 & 0.982 \\
Japan - Primary & 7 & 0.116 & 0.0043 & $0.00 \%$ & 0.005 & 0.878 \\
Australia - Primary & 8 & 0.173 & 0.0301 & $-1.10 \%$ & 0.755 & 0.005 \\
Australia - Secondary & 8 & 0.190 & 0.0307 & $-1.00 \%$ & 0.635 & 0.018 \\
Spain - Pre-Primary & 6 & 0.212 & 0.0407 & $-1.60 \%$ & 0.515 & 0.108 \\
U.S. - K-12 & 13 & 0.218 & 0.0153 & $-0.20 \%$ & 0.261 & 0.074 \\
England - Primary-Secondary & 9 & 0.233 & 0.0515 & $-1.60 \%$ & 0.719 & 0.351 \\
Spain - Secondary & 6 & 0.258 & 0.0291 & $-1.40 \%$ & 0.848 & 0.009 \\
Canada - Pre-Secondary & 8 & 0.310 & 0.0242 & $0.35 \%$ & 0.316 & 0.356 \\
\hline
\end{tabular}

Data source: Calculated from tables in case studies in Part 2.

Table 16. Basic Statistics and GRR of Gini Coefficient

\begin{tabular}{lcccccc}
\hline Country - Education level & Years & Mean & Std. Deviation & GRR & $\mathrm{R}^{2}$ & P-value \\
Japan - Lower Secondary & 7 & 0.059 & 0.0031 & $-0.10 \%$ & 0.140 & 0.408 \\
Japan - Upper Secondary & 7 & 0.062 & 0.0033 & $0.00 \%$ & 0.002 & 0.92 \\
Japan - Primary & 7 & 0.064 & 0.0024 & $0.00 \%$ & 0.004 & 0.893 \\
Australia - Primary & 8 & 0.075 & 0.0089 & $-0.30 \%$ & 0.732 & 0.007 \\
Australia - Secondary & 8 & 0.082 & 0.0055 & $-0.20 \%$ & 0.482 & 0.056 \\
England - Primary - Secondary & 9 & 0.087 & 0.0515 & $-0.44 \%$ & 0.684 & 0.351 \\
Spain - Pre-Primary & 6 & 0.110 & 0.0148 & $-0.50 \%$ & 0.463 & 0.137 \\
U.S. - K-12 & 13 & 0.117 & 0.0079 & $-0.10 \%$ & 0.273 & 0.067 \\
Spain - Secondary & 6 & 0.128 & 0.0165 & $0.80 \%$ & 0.790 & 0.018 \\
Canada - Pre-Secondary & 8 & 0.152 & 0.0110 & $0.17 \%$ & 0.218 & 0.360 \\
\hline
\end{tabular}

Data source: Calculated from tables in case studies. 
Table 17. School Funding Characteristics of Each Country

\begin{tabular}{|c|c|c|c|c|c|}
\hline & \multirow{2}{*}{$\begin{array}{c}\text { Education } \\
\text { Level }\end{array}$} & $\begin{array}{l}\text { Share of Gov. } \\
\text { funding }\end{array}$ & \multirow{2}{*}{$\begin{array}{l}\text { Share of Intergovernmental transfer } \\
\text { from central to regional government }\end{array}$} & \multirow{2}{*}{$\begin{array}{l}\text { School } \\
\text { Finance } \\
\text { Formula }\end{array}$} & \multirow{2}{*}{$\begin{array}{c}\text { Trend of } \\
\text { Centralization }\end{array}$} \\
\hline & & $\mathrm{C} \quad \mathrm{R} \quad \mathrm{L}^{*}$ & & & \\
\hline$\stackrel{\sim}{D}$ & $\mathrm{~K}-12$ & $10 \%, 39 \%, 52 \%$ & $\begin{array}{l}\text { Share of state government transfer to } \\
\text { local government decreased from } 50 \% \text { in } \\
1997 \text { to } 47 \% \text { in } 2006 \text {. Share of federal } \\
\text { government transfer to state government } \\
\text { increased from } 7 \% \text { in } 1997 \text { to } 9 \% \text { in } \\
2006 \text {. }\end{array}$ & Yes & $\begin{array}{l}\text { Decentralizing to } \\
\text { local } \\
\text { government }\end{array}$ \\
\hline 尚 & $\begin{array}{l}\text { Primary - } \\
\text { Secondary }\end{array}$ & $17 \%, 0 \%, 83 \%$ & $\begin{array}{l}\text { Share of central government to local } \\
\text { government increased from } 3.7 \% \text { to } 6.7 \% \\
\text { from } 1997 \text { to } 2003 \text {. }\end{array}$ & Yes & Centralizing \\
\hline \multirow{2}{*}{ 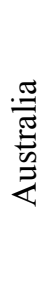 } & Primary & $18 \%, 82 \%, 0 \%$ & $\begin{array}{l}\text { Share of central government transfer to } \\
\text { regional government increased from } 13 \% \\
\text { to } 17 \% \text { from } 1997 \text { to } 2006 \text {. }\end{array}$ & \multirow{2}{*}{ Yes } & Centralizing \\
\hline & Secondary & $16 \%, 84 \%, 0 \%$ & $\begin{array}{l}\text { Share of central government to regional } \\
\text { government decreased from } 9 \% \text { to } 6 \% \\
\text { from } 1997 \text { to } 2006\end{array}$ & & Decentralizing \\
\hline \multirow{2}{*}{ 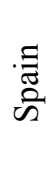 } & $\begin{array}{l}\text { Preschool- } \\
\text { Primary }\end{array}$ & $12 \%, 76 \%, 13 \%$ & \multirow{2}{*}{$\begin{array}{l}\text { Only general fiscal transfer for all } \\
\text { purpose. No special intergovernmental } \\
\text { transfer for education. }\end{array}$} & Yes & \multirow{2}{*}{$\begin{array}{l}\text { Decentralizing to } \\
\text { regional } \\
\text { government }\end{array}$} \\
\hline & Secondary & $13 \%, 84 \%, 3 \%$ & & Yes & \\
\hline 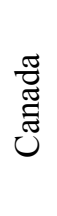 & $\begin{array}{l}\text { Preschool- } \\
\text { Secondary }\end{array}$ & $4 \%, 71 \%, 25 \%$ & $\begin{array}{l}\text { Share of regional government transfer to } \\
\text { local government increased from } 50 \% \text { in } \\
1997 \text { to } 63 \% \text { in } 2006 \text {. The central } \\
\text { government transfer was always less } \\
\text { than } 1 \% \text {. }\end{array}$ & Yes & Decentralizing \\
\hline \multirow{3}{*}{$\stackrel{\text { Eี }}{\stackrel{\Xi}{\leftrightarrows}}$} & Primary & $23 \%, 53 \%, 23 \%$ & \multirow{2}{*}{$\begin{array}{l}\text { Constant } 30 \% \text { transfer from central } \\
\text { government to regional government }\end{array}$} & \multirow{3}{*}{$\begin{array}{l}\text { For } \\
\text { school } \\
\text { official } \\
\text { cost }\end{array}$} & \multirow{3}{*}{$\begin{array}{l}\text { No trends, very } \\
\text { stable }\end{array}$} \\
\hline & $\begin{array}{l}\text { Lower } \\
\text { Secondary }\end{array}$ & $24 \%, 54 \%, 21 \%$ & & & \\
\hline & $\begin{array}{l}\text { Upper } \\
\text { Secondary }\end{array}$ & $3 \%, 91 \%, 6 \%$ & $\begin{array}{l}\text { Constant } 3 \% \text { transfer from central } \\
\text { government to regional government }\end{array}$ & & \\
\hline
\end{tabular}

Data source: OECD, authors' calculation.

*Latest year in the case studies in part 2. The order of the three numbers in each cell is share of central, regional, and local government spending. $\mathrm{C}$ is central government, $\mathrm{R}$ is regional government, and $\mathrm{L}$ is local government. 